\title{
Is There Not Sufficient Evidence to Show That Haemodiafiltration Is Superior to Conventional Haemodialysis in Treating End-Stage Kidney Disease Patients?
}

\author{
Bernard Canaud $^{\mathrm{a}, \mathrm{b}}$ Ellen Busink ${ }^{c}$ Christian Apel ${ }^{c}$ Sudhir K. Bowry ${ }^{d}$ \\ ${ }^{a}$ Centre of Excellence Medical, Fresenius Medical Care Deutschland, Bad Homburg, Germany; ${ }^{b}$ Montpellier \\ University, School of Medicine, Montpellier, France; ${ }^{c}$ Centre of Excellence Health Economics, Market Access and \\ Policy Affairs EMEA, Fresenius Medical Care Deutschland, Bad Homburg, Germany; ${ }^{d}$ Scientific Value Creation, \\ Fresenius Medical Care Deutschland, Bad Homburg, Germany
}

Evidence-based medicine (EBM) is currently perceived as the new paradigm and a "gold standard" for guiding treatment practice changes in clinical medicine, including nephrology [1]. EBM relies on evidence generated by clinical trials and/or other studies, the highest level being supported by prospective randomized controlled trials (RCTs) that form the basis of meta-analyses [2]. Based on these findings, best practices guidelines are graded from high to low levels and guidelines are developed to support physicians in their decisionmaking in clinical practice [3]. This process is recognized by both the scientific community as well as health care providers as the most appropriate approach to improve value-based care in medicine. Nephrology, including renal replacement therapy (RRT) options, is hence within the scope of both EBM and value-based healthcare [4].

Application of EBM related to end-stage kidney disease (ESKD) patients and renal replacement therapies is fraught with a number of difficulties: Foremost, randomized controlled studies are scarce, weak, or even inexistent, explaining why the present level of recommendations is relatively weak regarding best practice guidelines

\section{KARGER}

(c) 2018 S. Karger AG, Basel

E-Mail karger@karger.com

www.karger.com/bpu for dialysis and ESKD. Second, most seminal interventional RCTs in dialysis have failed to reach their primary objective (e.g., the HEMO study [5], MPO study [6] Nocturnal FHN [7], IDEAL [8], 4D [9]). Third, ESKD and uremia are highly complex pathologies that combine several metabolic disorders interacting with one another with the consequence that specific interventions focusing on any one component are likely to fail to improve or impact patient outcome [10]. Fourth, dialysis patients are mostly elderly ( $\sim 2 / 3$ are over 65 years) often having multiple comorbid conditions ( $60 \%$ with past history of severe cardiovascular event) with renal rRRT being just one component of the overall outcome-based risk profile [11]. Finally, practice patterns in the RRT field are highly diverse, as shown by the Dialysis Outcomes and Practice Patterns Study (DOPPS) initiative, meaning that centre or care provider effects are significant confounding factors towards the eventual clinical outcome of the dialysis patient [12].

Furthermore, it is imperative to recognize that studies addressing specific questions in the treatment of ESKD patients will never be addressed by interventional randomized prospective study for ethical or legal reasons. 
Would any ethics committee or executive review board agree to analyze patient outcomes in RCTs comparing peritoneal dialysis versus haemodialysis (HD)-treated patients, palliative care versus dialysis patients or dialysis versus kidney transplant patients? In such cases, the scientific community strongly advocates to consider moving to patient-centered care and to use cohort studies as valuable tools for providing answers to unanswered questions $[13,14]$. In order to minimize bias and confounders, it is proposed to use more refined epidemiologic tools (e.g., Propensity Score Matching, Inverse Probability Treatment Weighting) to account for these factors [15].

Haemodiafiltration (HDF), widely recognized as the most efficient as well as innovative RRT for ESKD patients [16-18], is also rightly the subject of scientific scrutiny, to assess the evidence-based facts that support its purported clinical superiority and its added value in the RRT field [19]. The question raised by Kawanishi [20] regarding the soundness of evidence base for HDF is certainly valid. Considering HDF as potentially the most superior therapy option in ESKD patients, it is then worthwhile to examine where we are today in terms of the soundness of the clinical evidence in order to identify gap and generate complementary research questions [21].

Short-term prospective interventional studies have provided intermediary outcomes showing that HDF enhanced solute removal of middle and large molecular size solutes and were associated with clinical benefits. HDF provides enhanced clearance of $\beta_{2}$-microglobulin compared to HD (30-40\% higher with HDF than with highflux HD) [22] and several large cohort studies have shown that the use of convective therapies has a beneficial impact on the development of $\beta_{2}$-microglobulin amyloidosis, reducing the incidence of carpal tunnel syndrome and other related manifestations $[23,24]$.

Although somewhat controversial, HDF tends to remove 15-20\% more phosphate than high-flux HD [25]. In the CONTRAST and French Convective versus Hemodialysis in Elderly (FRENCHIE) [26] studies, pre-dialysis serum phosphate levels were reduced by $5-10 \%$ and the percentage of patients reaching target pre-treatment serum phosphorus levels reached over $70 \%$, whereas no difference was found in the ESHOL and Turkish studies [22, 43].

Other prospective studies have shown that HDF was associated with lower levels of CRP and other sensitive biomarkers of inflammation (e.g., IL-6 and/or proinflammatory cells) [27, 28]. It remains unclear if HDF has significant benefits in anaemia management. Erythropoie- sis-stimulating agent dose has been reduced in several clinical studies in HDF-treated patients, the benefit being attributed to the combined effects of the higher removal of middle-sized uremic toxins and use of higher quality dialysate reducing inflammation $[29,30]$. No effect on erythropoiesis-stimulating agent resistance was found in a secondary analysis of CONTRAST data [31], whereas a significant decrease was observed in a large observational study for incident patients treated with EPO who received a high convective volume [32].

A significant reduction in episodes of intradialytic hypotension in HDF compared to conventional HD has been observed in some studies [33] but was blunted when thermal balance control was applied in HD [34]. Benefits of HDF have been ascribed to negative thermal balance due to the infusion of relatively cool substitution fluid. Interestingly, a recent prospective study showed that compared to high-flux HD, high-dose HDF was associated with preservation of muscle mass, increased protein intake and reduced inflammation, suggesting that HDF could help prevent protein-energy wasting [35].

Meta-analyses and/or systematic reviews comparing HDF to standard HD have reported conflicting results $[36,37]$. Unfortunately, most of these meta-analyses aggregated several different convection-based methods under the umbrella of "convective therapies" (e.g., HF, AFB, bag HDF...) and have been performed on historical cohort with outdated HDF practices, which in addition did not consider convective volume as a confounder [38,39].

Several retrospective large cohort studies suggested that HDF had beneficial effects on patient survival. The DOPPS first suggested that patients treated with relatively higher volume HDF (15-25 L/session) had a 35\% lower mortality than those treated with low-flux HD [40] even if this landmark finding could not be confirmed in a recent analysis of DOPPS [41].

Early results of cohort studies triggered 4 European RCTs to examine the survival rates associated with HDF. The primary analysis of 2 studies (CONTRAST [42] and Turkish [43]) failed to show beneficial effects on all-cause or cardiovascular mortality, although post hoc analyses of both studies showed beneficial effects in patients with high convection volumes ( $>22 \mathrm{~L} /$ session). The fact that two third of patients enrolled in CONTRAST did not achieve the targeted convection volume could be considered a weakness of that study [44]. However, recently, the same group reported that after the implementation of a stepwise approach and nurse training, over $80 \%$ of patients could achieve the threshold convection volume suggesting that failure to achieve the target was not inher- 
ent to HDF but related to its clinical implementation [45]. The third study (ESHOL), which achieved a convection volume of $22.9 \mathrm{~L}$ or more, demonstrated in the primary analysis of that patients treated with HDF had a 30\% lower risk of both all-cause and cardiovascular mortality than patients treated with high-flux HD [46]. The fourth study (FRENCHIE) was performed in patients over 65 years and focused on dialytic tolerance and patient reported outcomes [47]. The primary analysis showed that the proportion of patients experiencing at least one treatmentassociated adverse event did not differ between HDF and high-flux HD; the secondary analyses at the session level showed a significantly lower occurrence of intradialytic symptomatic hypotension and muscle cramps in the HDF-treated group.

All these studies indicate the critical question related to the magnitude of the convection volume, namely, the convective dose, as to how much of it should be delivered to achieve a positive outcome [48]. This question has been best addressed in a meta-analysis of individual patient data pooled from the 4 European RCTs (CONTRAST, Turkish study, ESHOL and FRENCHIE) [49, 50]. In brief, 769 of 2,793 patients had died, with 292 of the deaths being cardiovascular after a median follow-up of 2.5 years. HDF patients were then divided into tertiles based on delivered convection volume and mortality compared to those with HD using hazard ratios calculated using Cox proportional hazard regression models $[49,50]$. HDF was associated with a reduction in relative risk of mortality (all-cause and cardiovascular) for patients in the highest tertile of convection volume, whatever anthropometric standardizing factor was used [50]. In aggregate, HDF was shown to reduce the relative risk of all-cause mortality by $14 \%$ and cardiovascular mortality by $23 \%$ compared to HD [49]. The greatest benefit was for patients receiving the highest delivered convection volume $(>23$ $\mathrm{L} /$ session or $25.7 \mathrm{~L} / 1.73 \mathrm{~m}^{2}$ body surface area). Furthermore, in this pooled individual patient data meta-analysis, it was also shown that for some pre-selected subgroups of patients (e.g., elderly, cardiac, vintage on dialysis) HDF may have additional benefits with highest convective volumes [50].

With the extensive, worldwide clinical experience with the HDF modality, it is important to emphasize that there are no concerns about the safety and efficacy of sterilizing ultrafiltration for producing online substitution fluid and/or reliability of HDF monitors [51, 52]. To support this notion, one must keep in mind that today more than 180,000 patients are treated daily by HDF worldwide [53], with no reports questioning the safety the therapy or of

Conventional HD in Treating End-Stage

Kidney Disease Patients? online-prepared substitution fluid. On the contrary, all clinical findings suggest that outcome benefit is dose-related with a threshold volume of ultrafiltration that is equivalent to $23 \mathrm{~L} /$ session $\left(25.7 \mathrm{~L} / 1.73 \mathrm{~m}^{2}\right)$ in post-dilution mode [49]. From a clinical perspective, the critical challenge is now to implement high-volume HDF best practices in dialysis units and to provide adequate training to caregivers with precise targets and quality assurance control tools.

What then are the remaining questions to bridge the gap and prove the superiority of HDF in the RRT field? First, to confirm that high-volume HDF is indeed superior to conventional high-flux HD, an RCT adequately powered and designed addressing both patient outcome and patient perception is required. This question is currently being addressed by the CONVINCE study, a European Community-funded study, that plans to enroll 1800 prevalent ESKD patients and to compare in 2 arms (of 900 patients each), high-flux HD and high-volume HDF ( $>23$ L/session) over a 3-year follow-up period [54]. The primary objective is mortality (all-cause and cardiovascular causes) and the secondary objective is to obtain patient perception (Patient Reported Outcome and Patient Reported Experience) using an innovative tool [PROMIS]. Second, regarding the clear trend towards increasing convective volumes to improve outcomes, it is now time to revisit electrolyte prescription, that is, not just the $\mathrm{Na}$ as emphasized in the editorial of Kawanishi [20] but all electrolytes (e.g., $\mathrm{K}, \mathrm{HCO} 3, \mathrm{Ca}, \mathrm{Mg}$ ) in order to prevent longterm imbalance and their associated side effects. Third, it is imperative today to carry out solid health economic analyses alongside clinical trials to assess the outcome vs. cost aspect to guide non-clinical budget holders on valuebased renal care (e.g., hospitalization rate, vascular access dysfunction, anemia management with respect to the outcome/cost ratio) or to best integrate HDF in ESKD patient trajectory and/or to explore cause-specific morbidity and mortality $[55,56]$.

In conclusion, it is rather encouraging to witness increased scientific activity striving to prove clinical superiority and added value of HDF over conventional HD focusing on patient outcome-related RCT studies. However, this quest for more definitive evidence should not hinder or restrict clinician practitioners from prescribing HDF to patients who could already benefit from the modality today. Not offering potentially superior treatment options today could be perceived tomorrow as a lost opportunity of better outcomes for ESKD patients - once it is definitively proven in the future that HDF is indeed superior to conventional HD treatment options. 


\section{References}

1 The Gold Standard: The Challenge of Evidence-Based Medicine and Standardization in HealthCare. Edited by Stefan Timmermans and Marc Berg. Temple University Press, 2005. www.temple.edu/tempress.

2 Uhlig K, Balk EM, Lau J, Levey AS: Clinical practice guidelines in nephrology: for worse or for better. Nephrol Dial Transplant 2006; 21:1145-1153.

3 Kavanagh BP: The GRADE system for rating clinical guidelines. PLoS Med 2009; 6:e1000094.

4 Samuel J, Samuels J: Evidence-based practice in nephrology: systematic reviews. Adv Chronic Kidney Dis 2012;19:34-39.

5 Eknoyan G, Beck GJ, Cheung AK, Daugirdas JT, Greene T, Kusek JW, Allon M, Bailey J, Delmez JA, Depner TA, Dwyer JT, Levey AS, Levin NW, Milford E, Ornt DB, Rocco MV, Schulman G, Schwab SJ, Teehan BP, Toto R; Hemodialysis (HEMO) Study Group: Effect of dialysis dose and membrane flux in maintenance hemodialysis. N Engl J Med 2002; 347:2010-2019.

6 Locatelli F, Martin-Malo A, Hannedouche T, Loureiro A, Papadimitriou M, Wizemann V, Jacobson SH, Czekalski S, Ronco C, Vanholder R; Membrane Permeability Outcome (MPO) Study Group: Effect of membrane permeability on survival of hemodialysis patients. J Am Soc Nephrol 2009;20:645-654.

7 Rocco MV, Daugirdas JT, Greene T, Lockridge $\mathrm{RS}$, Chan $\mathrm{C}$, Pierratos $\mathrm{A}$, Lindsay $\mathrm{R}$, Larive B, Chertow GM, Beck GJ, Eggers PW, Kliger AS; FHN Trial Group: Long-term effects of frequent nocturnal hemodialysis on mortality: the frequent hemodialysis network (FHN) nocturnal trial. Am J Kidney Dis 2015; 66:459-468.

8 Cooper BA, Branley P, Bulfone L, Collins JF, Craig JC, Fraenkel MB, Harris A, Johnson DW, Kesselhut J, Li JJ, Luxton G, Pilmore A, Tiller DJ, Harris DC, Pollock CA; IDEAL Study: A randomized, controlled trial of early versus late initiation of dialysis. $\mathrm{N}$ Engl J Med 2010;363:609-619.

9 Wanner C, Krane V, März W, Olschewski M, Mann JF, Ruf G, Ritz E; German Diabetes and Dialysis Study Investigators: Atorvastatin in patients with type 2 diabetes mellitus undergoing hemodialysis. N Engl J Med 2005;353: 238-248.

10 Vanholder RC, Ringoir SM: Adequacy of dialysis: a critical analysis. Kidney Int 1992;42: 540-558.

11 Miskulin D, Bragg-Gresham J, Gillespie BW, Tentori F, Pisoni RL, Tighiouart H, Levey AS, Port FK: Key comorbid conditions that are predictive of survival among hemodialysis patients. Clin J Am Soc Nephrol 2009;4:18181826.

12 Robinson BM, Akizawa T, Jager KJ, Kerr PG, Saran R, Pisoni RL: Factors affecting outcomes in patients reaching end-stage kidney disease worldwide: differences in access to re- nal replacement therapy, modality use, and haemodialysis practices. Lancet 2016;388: 294-306.

13 O’Hare AM, Rodriguez RA, Bowling CB: Caring for patients with kidney disease: shifting the paradigm from evidence-based medicine to patient-centered care. Nephrol Dial Transplant 2016;31:368-375.

14 Canaud B, Blankestijn PJ, Davenport A, Bots ML: Reconciling and Closing the Loop Between Evidence-Based and Practice-Based Medicine: The Case for Hemodiafiltration. Am J Kidney Dis 2016;68:176-179.

15 Austin PC, Stuart EA: Moving towards best practice when using inverse probability of treatment weighting (IPTW) using the propensity score to estimate causal treatment effects in observational studies. Stat Med 2015; 34:3661-3679.

16 Ronco C: Hemodiafiltration: Evolution of a technique towards better dialysis care. Contrib Nephrol 2011;168:19-27.

17 Ronco C: Hemodiafiltration: technical and Clinical Issues. Blood Purif. 2015;40(suppl 1):2-11.

18 Gatti E, Ronco C: Seeking an optimal renal replacement therapy for the chronic kidney disease epidemic: the case for on-line hemodiafiltration. Contrib Nephrol 2011;175:170185.

19 Golper TA: Is hemodiafiltration ready for broader use? Kidney Int 2015;88:940-942.

20 Kawanishi $\mathrm{H}$ : Is there enough evidence to prove that hemodiafiltration is superior? Blood Purif 2018;46:3-6.

21 Canaud B, Grassmann A, Laura Scatizzi L, Daniele Marcelli D: Update on clinical evidence supporting hemodiafiltration; in Ayman Karkar (ed): "Advances in Hemodiafiltration”. InTechOpen, 2016, vol 6, pp 8897.

22 Maduell F, Navarro V, Cruz MC, Torregrosa E, Garcia D, Simon V, Ferrero JA: Osteocalcin and myoglobin removal in on-line hemodiafiltration versus low- and high-flux hemodialysis. Am J Kidney Dis 2002;40:582-589.

23 Locatelli F, Marcelli D, Conte F, Limido A, Malberti F, Spotti D: Comparison of mortality in ESRD patients on convective and diffusive extracorporeal treatments. The Registro Lombardo Dialisi E Trapianto. Kidney Int 1999;55:286-293.

24 Nakai S, Iseki K, Tabei K, Kubo K, Masakane I, Fushimi K, Kikuchi K, Shinzato T, Sanaka $\mathrm{T}$, Akiba T: Outcomes of hemodiafiltration based on Japanese dialysis patient registry. Am J Kidney Dis 2001;38(suppl 1):S212S216.

25 Lornoy W, De Meester J, Becaus I, Billiouw JM, Van Malderen PA, Van Pottelberge M: Impact of convective flow on phosphorus removal in maintenance hemodialysis patients. J Ren Nutr 2006;16:47-53.

26 Penne EL, van der Weerd NC, van den Dorpel MA, Grooteman MP, Lévesque R, Nubé MJ,
Bots ML, Blankestijn PJ, ter Wee PM; CONTRAST Investigators: Short-term effects of online hemodiafiltration on phosphate control: a result from the randomized controlled convective transport study (CONTRAST). Am J Kidney Dis. 2010;55:77-87.

27 Panichi V, Rizza GM, Paoletti S, Bigazzi R, Aloisi M, Barsotti G, Rindi P, Donati G, Antonelli A, Panicucci E, Tripepi G, Tetta C, Palla R; RISCAVID Study Group: Chronic inflammation and mortality in haemodialysis: effect of different renal replacement therapies. Results from the RISCAVID study. Nephrol Dial Transplant 2008;23:23372343.

28 Carracedo J, Merino A, Nogueras S, Carretero D, Berdud I, Ramírez R, Tetta C, Rodríguez M, Martín-Malo A, Aljama P: On-line hemodiafiltration reduces the proinflammatory CD14+CD16+ monocyte-derived dendritic cells: a prospective, crossover study. J Am Soc Nephrol 2006;17:2315-2321.

29 Panichi V, Scatena A, Rosati A, et al: Highvolume online haemodiafiltration improves erythropoiesis-stimulating agent (ESA) resistance in comparison with low-flux bicarbonate dialysis: results of the REDERT study. Nephrol Dial Transplant 2015;30: 682-689.

30 Bowry SK, Gatti E: Impact of hemodialysis therapy on anemia of chronic kidney disease: the potential mechanisms. Blood Purif 2011; 32:210-219.

31 van der Weerd NC, Den Hoedt CH, Blankestijn PJ, Bots ML, van den Dorpel MA, Lévesque R, Mazairac AH, Nubé MJ, Penne EL, ter Wee PM, Grooteman MP; CONTRAST Investigators. Resistance to erythropoiesis stimulating agents in patients treated with online hemodiafiltration and ultrapure low-flux hemodialysis: results from a randomized controlled trial (CONTRAST). PLoS One 2014;9:e94434.

32 Marcelli D, Bayh I, Merello JI, Ponce P, Heaton A, Kircelli F, Chazot C, Di Benedetto A, Marelli C, Ladanyi E, Kroczak M, Stuard S, Grassmann A, Scatizzi L, Brand K, Canaud B: Dynamics of the erythropoiesis stimulating agent resistance index in incident hemodiafiltration and high-flux hemodialysis patients. Kidney Int 2016;90:192-202.

33 Locatelli F, Altieri P, Andrulli S, Bolasco P, Sau G, Pedrini LA, Basile C, David S, Feriani M, Montagna G, Di Iorio BR, Memoli B, Cravero R, Battaglia G, Zoccali C. Hemofiltration and hemodiafiltration reduce intradialytic hypotension in ESRD. J Am Soc Nephrol 2010;21:1798-1807.

34 van der Sande FM, Kooman JP, Konings CJ, Leunissen KM: Thermal effects and blood pressure response during postdilution hemodiafiltration and hemodialysis: the effect of amount of replacement fluid and dialysate temperature. J Am Soc Nephrol 2001;12: 1916-1920. 
35 Molina P, Vizcaíno B, Molina MD, Beltrán S, González-Moya M, Mora A, Castro-Alonso C, Kanter J, Ávila AI, Górriz JL, Estañ N, Pallardó LM, Fouque D, Carrero JJ: The effect of high-volume online haemodiafiltration on nutritional status and body composition: the ProtEin Stores prEservaTion (PESET) study. Nephrol Dial Transplant 2017, EPub ahead of print.

36 Wang AY, Ninomiya T, Al-Kahwa A, Perkovic V, Gallagher MP, Hawley C, Jardine MJ: Effect of hemodiafiltration or hemofiltration compared with hemodialysis on mortality and cardiovascular disease in chronic kidney failure: a systematic review and meta-analysis of randomized trials. Am J Kidney Dis 2014; 63:968-978

37 Mostovaya IM, Blankestijn PJ, Bots ML, Covic A, Davenport A, Grooteman MP, Hegbrant J, Locatelli F, Vanholder R, Nubé MJ; EUDIAL - an official ERA-EDTA Working Group: Clinical evidence on hemodiafiltration: a systematic review and a meta-analysis. Semin Dial 2014;27:119-127.

38 Nistor I, Palmer SC, Craig JC, Saglimbene V, Vecchio M, Covic A, Strippoli GF: Convective versus diffusive dialysis therapies for chronic kidney failure: an updated systematic review of randomized controlled trials. Am J Kidney Dis 2014;63:954-967.

39 Bowry SK, Apel C, Canaud B: Assessment of clinical evidence for convective dialysis therapies. Am J Kidney Dis 2014;64:820.

40 Canaud B, Bragg-Gresham JL, Marshall MR, Desmeules S, Gillespie BW, Depner T, Klassen $\mathrm{P}$, Port FK: Mortality risk for patients receiving hemodiafiltration versus hemodialysis: European results from the DOPPS. Kidney Int 2006;69:2087-2093.

41 Locatelli F, Karaboyas A, Pisoni RL, Robinson BM, Fort J, Vanholder R, Rayner HC, Kleophas W, Jacobson SH, Combe C, Port FK, Tentori F: Mortality risk in patients on hemodiafiltration versus hemodialysis: a "realworld" comparison from the DOPPS. Nephrol Dial Transplant 2017, Epub ahead of print.

42 Grooteman MP, van den Dorpel MA, Bots ML, Penne EL, van der Weerd NC, Mazairac $\mathrm{AH}$, den Hoedt $\mathrm{CH}$, van der Tweel I, Lévesque R, Nubé MJ, ter Wee PM, Blankestijn PJ; CONTRAST Investigators: Effect of online hemodiafiltration on all-cause mortality and cardiovascular outcomes. J Am Soc Nephrol 2012;23:1087-1096.

43 Ok E, Asci G, Toz H, Ok ES, Kircelli F, Yilmaz M, Hur E, Demirci MS, Demirci C, Duman S, Basci A, Adam SM, Isik IO, Zengin M, Suleymanlar G, Yilmaz ME, Ozkahya M; Turkish Online Haemodiafiltration Study: Mortality and cardiovascular events in online haemodiafiltration (OL-HDF) compared with highflux dialysis: results from the Turkish OLHDF Study. Nephrol Dial Transplant 2013; 28:192-202.

44 Penne EL, van der Weerd NC, Bots ML, van den Dorpel MA, Grooteman MP, Lévesque R, Nubé MJ, Ter Wee PM, Blankestijn PJ; CONTRAST Investigators: Patient- and treatmentrelated determinants of convective volume in post-dilution haemodiafiltration in clinical practice. Nephrol Dial Transplant 2009;24: 3493-3499

45 de Roij van Zuijdewijn CLM, Chapdelaine I, Nubé MJ, Blankestijn PJ, Bots ML, Konings CJAM, Kremer Hovinga TK, Molenaar FM, van der Weerd NC, Grooteman MPC: Achieving high convection volumes in postdilution online hemodiafiltration: a prospective multicenter study. Clin Kidney J 2017;10:804812.

46 Maduell F, Moreso F, Pons M, Ramos R, Mora-Macià J, Carreras J, Soler J, Torres F, Campistol JM, Martinez-Castelao A; ESHOL Study Group: High-efficiency postdilution online hemodiafiltration reduces all-cause mortality in hemodialysis patients. J Am Soc Nephrol 2013;24:487-497.

47 Morena M, Jaussent A, Chalabi L, Leray-Moragues $\mathrm{H}$, Chenine L, Debure A, Thibaudin D, Azzouz L, Patrier L, Maurice F, Nicoud P, Durand C, Seigneuric B, Dupuy AM, Picot MC, Cristol JP, Canaud B; FRENCHIE Study Investigators: Treatment tolerance and patientreported outcomes favor online hemodiafiltration compared to high-flux hemodialysis in the elderly. Kidney Int 2017;91:1495-1509

48 Canaud B, Bowry SK: Emerging clinical evidence on online hemodiafiltration: does volume of ultrafiltration matter? Blood Purif 2013;35:55-62.

49 Peters SA, Bots ML, Canaud B, Davenport A, Grooteman MP, Kircelli F, Locatelli F, Maduell F, Morena M, Nubé MJ, Ok E, Torres F, Woodward M, Blankestijn PJ; HDF Pooling
Project Investigators: Haemodiafiltration and mortality in end-stage kidney disease patients: a pooled individual participant data analysis from four randomized controlled trials. Nephrol Dial Transplant 2016;31:978-984.

50 Davenport A, Peters SA, Bots ML, Canaud B, Grooteman MP, Asci G, Locatelli F, Maduell F, Morena M, Nubé MJ, Ok E, Torres F, Woodward M, Blankestijn PJ: Higher convection volume exchange with online hemodiafiltration is associated with survival advantage for dialysis patients: the effect of adjustment for body size. Kidney Int 2016;89: 193-199.

51 Corradi V, Cruz D, Vázquez-Rangel A, Furlan F, Grillone R, Bonaccorsi A, Cazzavillan S, de Cal M, Frisone P, Morea A, Brendolan A, Rassu M, Ronco C: Purity and stability of online-prepared hemodiafiltration fluid after storage. Blood Purif 2013;35:112-118.

52 Penne EL, Visser L, van den Dorpel MA, van der Weerd NC, Mazairac AH, van Jaarsveld BC, Koopman MG, Vos P, Feith GW, Kremer Hovinga TK, van Hamersvelt HW, Wauters IM, Bots ML, Nubé MJ, Ter Wee PM, Blankestijn PJ, Grooteman MP: Microbiological quality and quality control of purified water and ultrapure dialysis fluids for online hemodiafiltration in routine clinical practice. Kidney Int 2009;76:665-672.

53 Sichart JM, Moeller S: Utilization of hemodiafiltration as treatment modality in renal replacement therapy for end-stage renal disease patients: a global perspective. Contrib Nephrol 2011;175:163-169.

54 The Comparison of High-Dose Haemodiafiltration (HDF) with High-Flux Haemodialysis (HD) - CONVINCE. Horizon 2020. https:// ec.europa.eu/programmes/horizon2020/.

55 Ramponi F, Ronco C, Mason G, Rettore E, Marcelli D, Martino F, Neri M, Martin-Malo A, Canaud B, Locatelli F: Cost-effectiveness analysis of online hemodiafiltration versus high-flux hemodialysis. Clinicoecon Outcomes Res 2016;8:531-540.

56 Nubé MJ, Peters SAE, Blankestijn PJ, Canaud B, Davenport A, Grooteman MPC, Asci G, Locatelli F, Maduell F, Morena M, OkE, Torres F, Bots ML; HDF Pooling Project investigators: Mortality reduction by post-dilution onlinehaemodiafiltration: a cause-specific analysis. Nephrol Dial Transplant. 2017;32:548-555. 